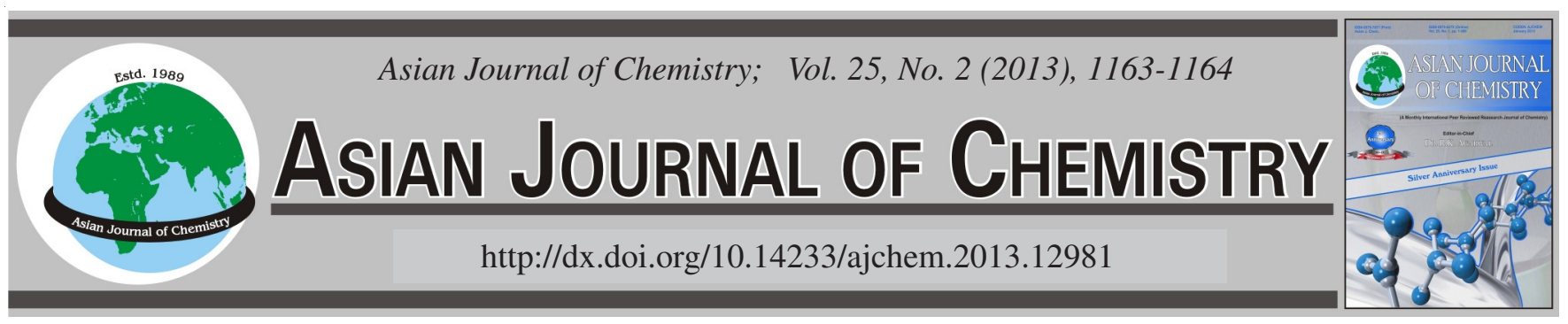

NOTE

\title{
Chemical Investigation of Paederia foetidae (Rubiaceae)
}

\author{
N. UdDin ${ }^{1}$, M.K. Hossain ${ }^{2}$, M.R. Haque ${ }^{2}$ and C.M. HASAN ${ }^{2, *}$
}

${ }^{1}$ Phytochemical Research Laboratory, Department of Pharmaceutical Chemistry, Faculty of Pharmacy, University of Dhaka, Dhaka-1000, Bangladesh

${ }^{2}$ Department of Pharmacy, Manarat International University, Mirpur-1, Dhaka-1216, Bangladesh

*Corresponding author: E-mail: cmhasan@gmail.com

(Received: 1 November 2011;

Accepted: 31 August 2012)

AJC-12068

Chemical investigation on the methanol extract of Paederia foetidae, using vacuum liquid chromatography resulted in the isolation of
ethyl $p$-methoxy-trans-cinnamate. The structure was established by extensive spectral analysis (PMR, CMR, 2D NMR and MS etc.) and
comparing with the published data. This is the first report of this compound from Rubiaceae family.
Key Words: Ethyl $p$-methoxy-trans-cinnamate, Rubiaceae, Paederia foetidae.

Paederia foetidae is familiar with common names Skunkvine; Stinkvine or Chinese Fever Vine ${ }^{1}$. It is native to temperate and tropical Asia and has become naturalized in the Mascarenes, Melanesia, Polynesia and the Hawaiian Islands². Paederia foetida is known for the strong, sulfurous odour exudates when its leaves or stems are crushed or bruised. This is because the oil responsible for the smell and found primarily within the leaves, contains sulphur compounds, including largely dimethyl disulphide ${ }^{3}$. Paederia species showed a lot of pharmacologic activities. Previously reported potential activities like antiinflammatory activity of the butanol fraction of a methanol extract of the defatted leaves of Paederia foetida ${ }^{4}$. The analgesic effect of iridoid glycoside of Paederia scandens was studied by the formalin, acetic acid-induced writhing methods of mice ${ }^{5}$. The antidiarrhoeal activity of the ethanol extract of Paederia foetida Linn. ${ }^{6}$, antinociceptive activity of paederosidic acid methyl ester (PAME) from the $n$-butanol fraction of Paederia scandens in mice ${ }^{7}$, antimicrobial activities ${ }^{8}$ and antioxidant activity of phenolic content of Paederia foetida and Syzygium aqueum ${ }^{9}$.

The NMR spectra were recorded using a Bruker AMX400 instrument. PTLC $(20: 20 \mathrm{~cm})$ and TLC $(20: 5 \mathrm{~cm})$ were carried out using Merck Silica gel $60 \mathrm{PF}_{254}$ on glass plates at a thickness of $0.5 \mathrm{~mm}$. Spots on PTLC and TLC plates were visualized by spraying with $10 \%$ vanillin in sulfuric acid followed by heating for $5 \mathrm{~min}$ at $110^{\circ} \mathrm{C}$.

General procedures: Plant sample of Paederia foetidae was collected from Rangpur, Bangladesh in April 2010. The plant was identified by Prof. Abul Hassan, Department of Botany, University of Dhaka, Bangladesh, where a voucher specimen (accession number DUSH 9600) has been deposited for further reference.

The aerial plant part were cut into small pieces and then dried under sun for several days. The dried samples were then ground in coarse powder using high capacity grinding machine. This sample was preserved for future use marking in air tight container as it contains sulfurous odour.

Extraction and isolation: The dried plant without roots $(600 \mathrm{~g})$ of Paederia foetidae was soaked in $1.5 \mathrm{~L}$ methanol for 7 days and filtered through a cotton plug followed by Whatman filter paper No. 1. Approximately $5.0 \mathrm{~g}$ of the crude extract was obtained through evaporation of solvent in vacuo. The crude extract was then subjected to VLC over silica gel using petroleum ether (60-800), ethyl acetate and methanol in order of increasing polarity. The VLC fraction eluted with $40 \%$ ethyl acetate in petroleum ether was evaporated to dryness and the dried mass was subjected to sephadex column using $40 \%$ chloroform in $n$-hexane, which afforded compound $\mathbf{1}$ (3.8 mg).

\section{Detection method}

Ethyl p-methoxy-trans-cinnamate (1): Fine colourless needles; ESIMS: m/z $[\mathrm{M}+\mathrm{H}]^{+}$207; ${ }^{1} \mathrm{H}$ NMR $(400 \mathrm{MHz}$, $\mathrm{CDCl}_{3}$, Table-1); ${ }^{13} \mathrm{C}$ NMR (100 MHz, $\mathrm{CDCl}_{3}$, Table-1).

Compound 1 was isolated from the methanol extract as fine colorless needles, which appeared as a dark quenching 


\begin{tabular}{|c|c|c|c|}
\hline \multicolumn{4}{|c|}{$\begin{array}{c}\text { TABLE-1 } \\
\text { SPECTRAL DATA OF } 1 \text { (IN CDCl }{ }_{3} \text {, TMS) }\end{array}$} \\
\hline No & ${ }^{1} \mathrm{H}$ NMR & ${ }^{13} \mathrm{C}$ NMR & HMBC \\
\hline 1 & - & $144.36(\mathrm{~s})$ & \\
\hline 2 and 6 & $7.47(\mathrm{~d}, J=8.8 \mathrm{~Hz})$ & $129.70(d)$ & $\mathrm{C}-1, \mathrm{C}-3$ \\
\hline 3 and 5 & $6.89(\mathrm{~d}, J=8.8 \mathrm{~Hz})$ & $114.32(\mathrm{~d})$ & $\mathrm{C}-1$, \\
\hline 4 & - & $161.38(\mathrm{~s})$ & \\
\hline $1^{\prime}$ & $7.63(\mathrm{~d}, J=16.0 \mathrm{~Hz})$ & $127.21(\mathrm{~d})$ & C-6, C-3' \\
\hline $2^{\prime}$ & $6.30(\mathrm{~d}, J=16.0 \mathrm{~Hz})$ & $115.76(d)$ & C-1 \\
\hline 3' & - & $167.38(\mathrm{~s})$ & \\
\hline C-1" & $4.24(\mathrm{q}, J=7.2 \mathrm{~Hz})$ & $60.30(\mathrm{t})$ & C-3', C-1"' \\
\hline C-2" & $1.33(\mathrm{t}, J=7.2 \mathrm{~Hz})$ & $14.37(q)$ & $\mathrm{C}-1 "$ \\
\hline$-\mathrm{OCH}_{3}$ & 3.83 & $55.39(\mathrm{q})$ & C-4 \\
\hline
\end{tabular}

spot on TLC plate under UV light at $254 \mathrm{~nm}$. The compound $\mathbf{1}$ gave a pseudo mol. ion at $207\left(\mathrm{~m}^{+}+\mathrm{H}\right)$ corresponding to mol. wt 206 and formula $\mathrm{C}_{12} \mathrm{H}_{14} \mathrm{O}_{3}$. The structure was established as ethyl $p$-methoxy-trans-cinnamate by comparing the spectral data $\left({ }^{1} \mathrm{H}\right.$ NMR) with those reported for this compound ${ }^{10,11}$. The structure was further substantiated by NOESY, COSY, HSQC and $\mathrm{HMBC}$ experiments. This is the first report of this compound from Rubiaceae family.

In ${ }^{1} \mathrm{H}$ NMR (Table-1) spectra the methoxy group appeared as a singlet at $\delta 3.83$. Two $2 \mathrm{H}$ doublets were observed for four aromatic protons at $\delta 6.89$ and $\delta 7.47$. The splitting pattern and coupling constants $(J=8.8 \mathrm{~Hz})$ of the aromatic protons indicated the presence of a 1,4-disubstituted benzene ring. It also showed a $2 \mathrm{H}$ quartet at $\delta 4.24$ and a three methyl triplet at $\delta 1.33$ for a primary methyl group. The trans-olefinic protons, H-1' and H-2' appeared as doublets $(J=16 \mathrm{~Hz})$ at $\delta 7.63$ and 6.30 , respectively. The relatively low field resonance for $\mathrm{H}-1$ ' could be explained by its $\beta$-position to the carbonyl group. ${ }^{13} \mathrm{C}$ NMR (Table-1) displayed 12 carbons in the skeleton. To our knowledge there is no report of ${ }^{13} \mathrm{C}$ NMR of this compound. HMBC experiments showed the connectivity of $\mathrm{CH}_{2}$ proton at $\delta 4.24$ with $\mathrm{CO}$ carbon $\left(\delta_{\mathrm{C}} 167.38\right)$ of the ester group.

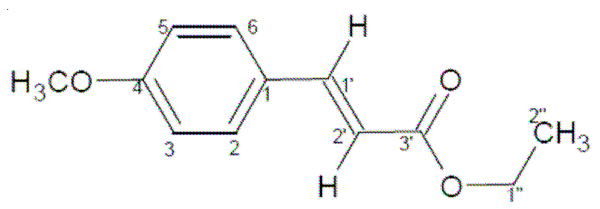

Fig. 1. Ethyl p-methoxy-trans-cinnamate

\section{REFERENCES}

1. Invasive Species Specialist Group (ISSG), Ecology of Paederia foetida (2010).

2. Germplasm Resources Information Network (GRIN), Taxonomy for Plants, National Germplasm Resources Laboratory, Beltsville, Maryland: USDA, ARS, National Genetic Resources Program (2010).

3. K.C. Wong and G.L. Tan, Flavour Fragr. J., 9, 25 (1994).

4. S. De, B. Ravishankar and G.C. Bhavsar, J. Ethnopharmacol., 43, 31 (1994).

5. L. Mei, Z. Lanlan, W. Lu and P. Mingqun, Pharmacol. Clin. Chin. Mater. Med., 24, 43 (2008).

6. S. Afroz, M. Altamira, M.T.H. Khan, S. Jabbar, N. Nahar and M.S.K. Choudhuri, J. Ethnopharmacol., 105, 125 (2006).

7. Y.F. Chen, Q.Y. Zhang, J.Z. Wang, L. Nan, K. Rahman, H.C. Zheng and L.P. Qin, Die Pharmazie-Inter J. Phar. Sci., 62, 943 (2007).

8. R. Haider, A.K. Khan, K.M. Aziz, A. Chowdhury and I. Kabir, Trop. Geogr. Med., 43, 266 (1991).

9. H. Osman, A.A. Rahim, N.M. Isa and N.M. Bakhir, Molecules, 14, 970 (2009).

10. K. Kobayashi, M. Ueno and Y. Kondo, Supplementary Material (ESI) for Chemical Communications, The Royal Society of Chemistry, vol. 1 (2006).

11. C. Pandji, C. Grimm, V. Wray, L. Witte and P. Proksch, Phytochemistry, 34, 415 (1993). 